\title{
THE EFFECT OF OZONE FEEDING MODE ON THE EFFECTIVENESS OF NO OXIDATION
}

\author{
Maciej Jakubiak, Włodzimierz Kordylewski* \\ Wrocław University of Technology, Faculty of Mechanical and Power Engineering, Institute of \\ Power Engineering and Fluid Mechanics, Wybrzeże Wyspiańskiego 27, 50 - 370 Wrocław, Poland
}

\begin{abstract}
The influence of ozone injection mode on the effectiveness of nitrogen monoxide oxidation to nitrogen dioxide by ozone in a flow reactor was investigated experimentally in laboratory apparatus. Nitrogen monoxide was diluted to the mole fraction $100 \mathrm{ppm}$ in air which served as the carrier gas flowing through the tube of the diameter $D=60 \mathrm{~mm}$ into which ozone was injected. The effects of a number of ozone injecting nozzles and their configuration on the effectiveness of NO oxidation were examined. In the closest vicinity from the injection site the counter-current injection mode appeared to be superior to the co-current injection mode, but in areas located further from the injection site both injection systems were almost equally effective.
\end{abstract}

Keywords: de-NOx, ozone, mixing

\section{INTRODUCTION}

The new EU Directive 2010/75/EU of 24 Nov. 2010 on industrial emissions (IED) established special provisions for combustion plants (Directive2010/75/EU). The IED emission limit values for waste gases are more stringent than limits of the previous (LCP) Directive (Directive2001/80/EC). For example, the $\mathrm{NO}_{\mathrm{x}}$ emission from "new" large coal-fired combustion plants should not exceed 150 $\mathrm{mg} / \mathrm{m}^{3}$ (at a standardised $\mathrm{O}_{2}$ content of $6 \%$ for solid fuels) after 1 Jan. 2016. For "old" coal-fired combustion plants the $\mathrm{NO}_{\mathrm{x}}$ emission limit values remain on the same level $200 \mathrm{mg} / \mathrm{m}^{3}\left(6 \% \mathrm{O}_{2}\right)$, although the total rated thermal input was lowered from 500 to $100 \mathrm{MW}_{\mathrm{t}}$ (Directive2010/75/EU and2001/80/EC). It means that for smaller combustion plants it will be impossible to meet the emission limit values applying only low- $\mathrm{NO}_{\mathrm{x}}$ combustion methods and that the after-boiler flue gas treatment based technologies have to be used.

Selective catalytic reduction (SCR) is considered to be the best available technology (BAT), because its effectiveness of $\mathrm{NO}_{\mathrm{x}}$ abatement could reach 95\% (Van der Kooij et al., 1997). However, the investment, maintenance and exploitation costs of the method are considered high, especially for smaller units $\left(<300 \mathrm{MW}_{\mathrm{t}}\right)$ and this is the reason that in Polish pulverized coal-fired power plants low$\mathrm{NO}_{\mathrm{x}}$ combustion systems have been commonly applied to control $\mathrm{NO}_{\mathrm{x}}$ emissions. Currently, there is an increasing need of an auxiliary method for further reduction of $\mathrm{NO}_{\mathrm{x}}$ emissions to satisfy the level of $200 \mathrm{mg} / \mathrm{m}^{3}\left(6 \% \mathrm{O}_{2}\right)$ at a reasonable cost. This is not only Polish problem, because also in the U.S.A. power generating companies are looking for reliable, cost effective technologies for $\mathrm{NO}_{\mathrm{x}}$ abatement (Schimmoller, 2003). 
One of such promising solutions has been proposed by the U.S.A. company Mobotec. The solution is a combination of an aggressive air staging called ROFA (Rotating Overfire Air) and SNCR (selective non-catalytic reduction) (Błasiak, 2008). Unfortunately, ammonia applied directly or indirectly from urea is not completely reacted in the furnace and ammonia leakage could be a problem. The reburning technology should also be mentioned in which substantial progress has been made during the recent fifteen years (Carlin et al., 2009; Kordylewski et al., 2006; Maly et al., 1999; Werle and Wilk, 2011).

An interesting alternative to commercial methods of flue gas denitrification are wet processes for simultaneous removal of $\mathrm{NO}_{\mathrm{x}}, \mathrm{SO}_{2}$ and $\mathrm{Hg}$. Although they have been known much earlier (Ellison, 2003), the methods of wet flue gas desulphurization (FGD) were not so widely disseminated then as they are nowadays. Concerning $\mathrm{NO}_{\mathrm{x}}$ removal, the methods are based on preliminary oxidation of $\mathrm{NO}$ and absorption of $\mathrm{NO}_{2}$ and higher nitrogen oxides in alkaline solutions. Also, metallic mercury $\mathrm{Hg}^{0}$ after oxidation could be efficiently scrubbed in alkaline solutions (Vosteen et al., 2006). Particularly limestone-based wet scrubbers commonly used for the control of $\mathrm{SO}_{2}$ emissions can be successfully adopted for control of $\mathrm{NO}_{\mathrm{x}}$ and $\mathrm{Hg}$ emissions by the retention of their oxidized forms (Wang et al., 2007).

Although NO pre-oxidation can proceed in gas- or in liquid phase, the former is more economic because it can be done in a flue gas channel. The most efficient gaseous oxidant is ozone, which converts $\mathrm{NO}$ to $\mathrm{NO}_{2}$ rapidly. However, its performance depends on many factors (Prather and Logan, 1994). One of these is direct contact of $\mathrm{NO}$ and $\mathrm{O}_{3}$ in flue gas because ozone is an active medium which could react with other compounds and quickly decompose.

The paper presents results of experimental studies on NO oxidation by ozone in flow conditions performed in a laboratory apparatus. The main objective of the study was to examine the influence of feeding mode of ozone and NO in the carrier gas on the effectiveness of NO oxidation. The investigations were conducted in a tubular flow reactor which could imitate the flue gas channel in a coal-fired power plant.

\section{MECHANISM OF NO OXIDATION BY OZONE}

Ozone is a very active oxidant which effectively oxidizes nitrogen monoxide to nitrogen dioxide $\left(\mathrm{NO}_{2}\right)$ (Puri, 1995):

$$
\mathrm{NO}+\mathrm{O}_{3} \rightarrow \mathrm{NO}_{2}+\mathrm{O}_{2}
$$

The chemical reaction (1) is fast at ambient temperature and has small activation energy $\mathrm{E}=13300$ $\mathrm{J} / \mathrm{mol}$ (NIST, 2010). At elevated temperature ozone undergoes thermal dissociation (Ozonek, 2003):

$$
\mathrm{O}_{3}+\mathrm{M}=\mathrm{O}_{2}+\mathrm{O}+\mathrm{M}
$$

and the released oxygen atoms quickly react with other compounds of atmosphere, such as (Prather and Logan, 1994):

$$
\mathrm{O}+\mathrm{H}_{2} \mathrm{O} \rightarrow 2 \mathrm{OH}
$$

and

$$
\mathrm{O}+\mathrm{O}_{3} \rightarrow 2 \mathrm{O}_{2}
$$

The presence of free oxygen atoms could be an additional source of $\mathrm{NO}_{2}$ due to the reaction (Wang et al. 2006):

$$
\mathrm{NO}+\mathrm{O}+\mathrm{M}=\mathrm{NO}_{2}+\mathrm{M}
$$

Nitrogen dioxide is practically the only product of NO oxidation by ozone at the sub-stoichiometric conditions $\left(\mathrm{O}_{3} / \mathrm{NO}<1\right)$ (Nelo et al., 1997). If ozone assumes over-stoichiometric mole fractions 
$\left(\mathrm{O}_{3} / \mathrm{NO}>1\right), \mathrm{O}_{3}$ could also react with $\mathrm{NO}_{2}$ producing nitrogen trioxide:

$$
\mathrm{NO}_{2}+\mathrm{O}_{3} \rightarrow \mathrm{NO}_{3}+\mathrm{O}_{2}
$$

which could lead to dinitrogenpentoxide formation:

$$
\mathrm{NO}_{2}+\mathrm{NO}_{3} \rightarrow \mathrm{N}_{2} \mathrm{O}_{5}
$$

In the field of deNOx process, it is a desired effect because extremely soluble $\mathrm{N}_{2} \mathrm{O}_{5}$ is effectively absorbed in water solutions (Nelo et al., 1997).

This short characteristic of the mechanism of NO oxidation by ozone indicates that ozone could be an effective factor in denitrification of flue gas from combustion processes. However, in practice the effectiveness of NO oxidation is impaired because ozone could react also with other compounds and some additional effects occur in the flue gas channel. Delay in $\mathrm{O}_{3}$ and NO contact in the carrier gas enhances the "wall effects" in which ozone decays. The same effect is caused by solid particles in flue gas. The elevated temperature and water in flue gas reduce ozone concentration (Ozonek, 2003). This means that conditions of $\mathrm{NO}$ oxidation by ozone should be controlled and that rapid mixing of reactants could improve the effectiveness of $\mathrm{NO}$ oxidation by $\mathrm{O}_{3}$.

\section{EXPERIMENTAL}

The experimental studies were conducted in the laboratory apparatus shown schematically in Fig. 1.

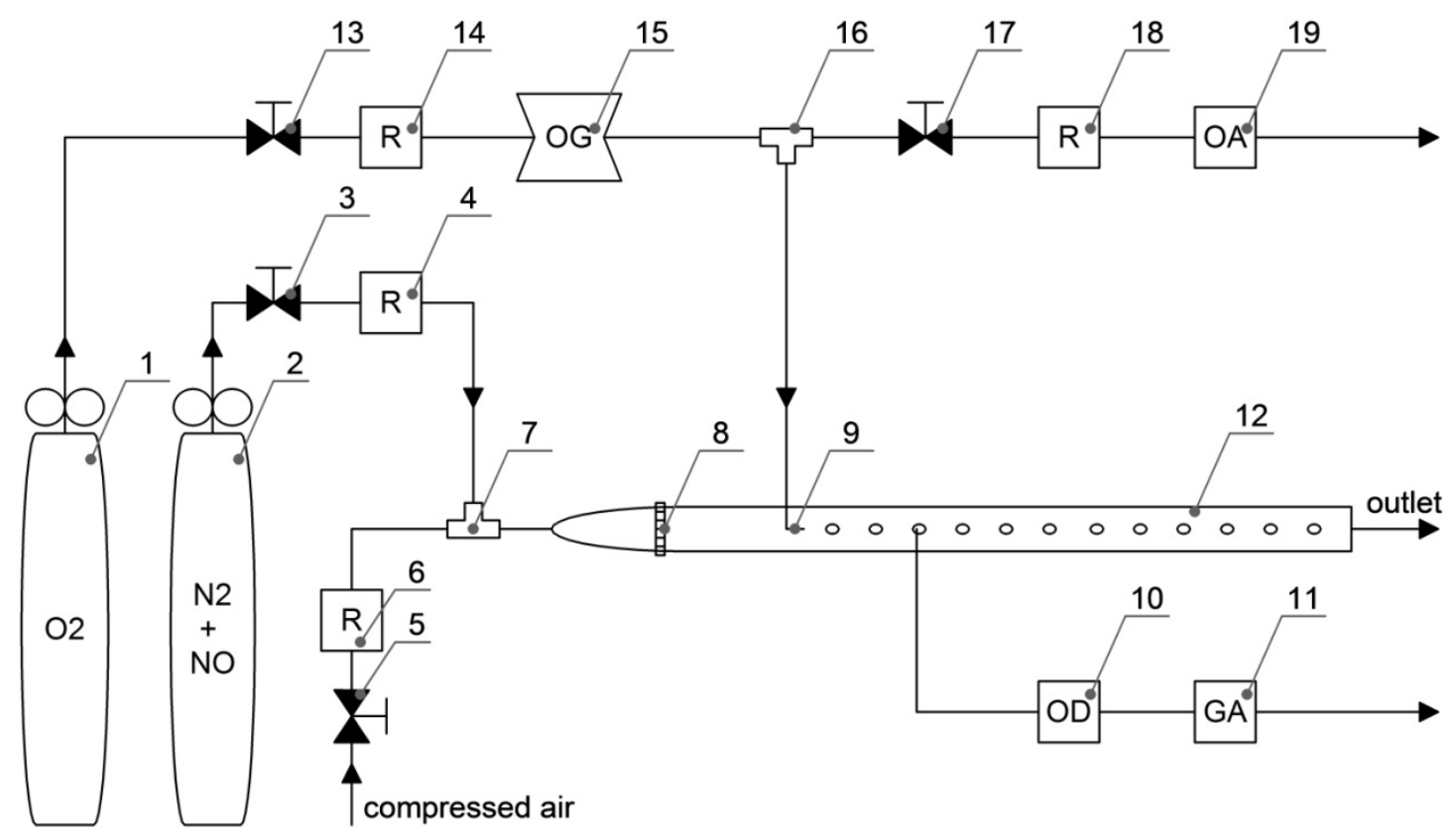

Fig. 1. Scheme of the laboratory apparatus: 1 - cylinder of $\mathrm{O}_{2}, 2-$ cylinder of $\mathrm{NO}\left(\mathrm{N}_{2}+2.5 \% \mathrm{NO}\right), 3,5,13,17-$ valves, 4, 6, 14, 18 - rotameters, 7, 16 - T connectors, 8 - grid, 9 - ozone injector, 10 - ozone destructor, 11 gas analyser, 12 - flow reactor, 15 - ozone generator, 19 - ozone analyser

The oxidation of $\mathrm{NO}$ by $\mathrm{O}_{3}$ proceeded in a tubular reactor (12) of a plexiglass tube $2 \mathrm{~m}$ long with the inner diameter $D=60 \mathrm{~mm}$. Along the reactor's axis there were 12 holes in a distance of $10 \mathrm{~cm}$ one from another through which a probe of the gas analyzer (11) was inserted (Fig. 2). In the entry of the flow reactor there was a steel grid with the mesh $0.5 \times 0.5 \mathrm{~mm}$ smoothing the radial profile of velocity and generating turbulence. 
a)

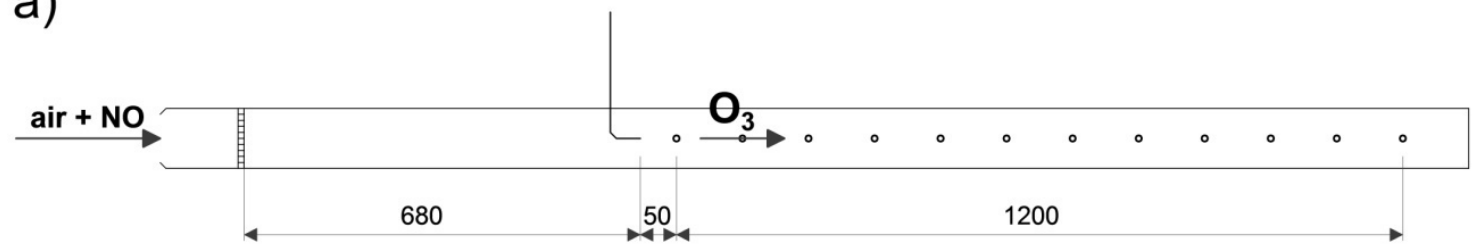

b)

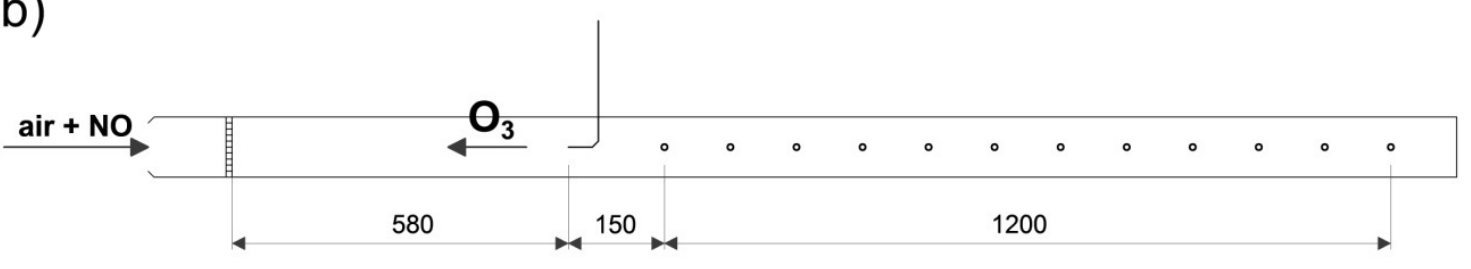

Fig. 2. Position of measurement sites in the flow reactor, a) co-current injection, b) counter-current injection

Dried air supplied into the reactor (12) by the compressor was used as the carrier gas, which was doped by $\mathrm{NO}$ diluted in $\mathrm{N}_{2}$ from the gas cylinder (2). The initial mole fraction of $\mathrm{NO}$ in the carrier gas was $100 \mathrm{ppm}$.

Ozone $\left(10 \div 20 \mathrm{~g}\right.$ of $\mathrm{O}_{3}$ per $\mathrm{m}^{3}$ of oxygen) was injected co- or counter-current into the carrier gas by: a single $(n=1)$, double $(n=2)$ and four nozzles $(n=4)$ with the inner diameter of $d=0.52 \mathrm{~mm}$ each (Fig. 3).

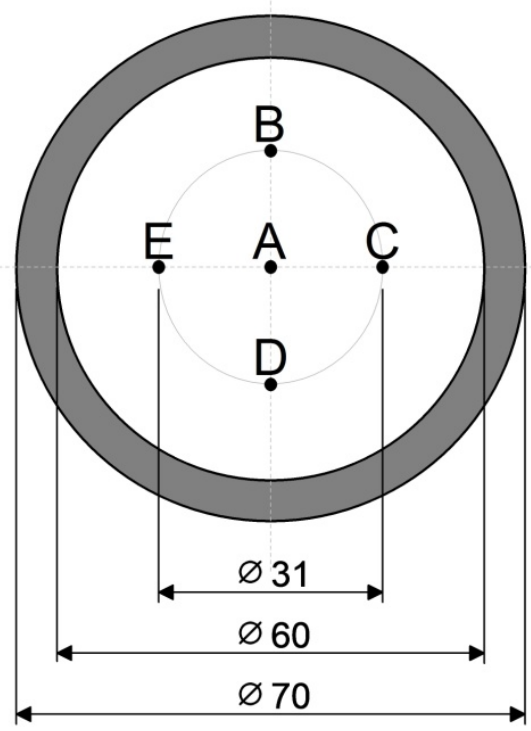

Fig. 3. Scheme of ozone injectors location, $\mathrm{A}-$ single nozzle $(n=1), \mathrm{B}$ and $\mathrm{D}-$ two $(n=2), \mathrm{B}, \mathrm{C}, \mathrm{D}$ and $\mathrm{E}-$ four nozzles $(n=4)$

Ozone was produced from oxygen at the rate from 3.4 to $7.4 \mathrm{~g} \mathrm{O}_{3}$ per hour by the corona discharge generator (15) of the Trailigaz. In order to evaluate the ozone mole fraction in oxygen a portion of gas stream $\left(15 \mathrm{dm}^{3} / \mathrm{h}\right)$ from the ozone generator (15) was directed into the ozone analyzer (19) BMT 964 BT model of BMT MESSTECHNIK GmBH.

The mole fractions of $[\mathrm{NO}]$ and $\left[\mathrm{NO}_{2}\right]$ in the carrier gas were measured in selected sites in the reactor's axis by the gas analyser Testo 350xl (11) (Fig. 1). The electrochemical sensors of the gas analyzer were protected against the residual ozone by a thermal destructor of ozone (10). 
The flow rates maintained in the apparatus and some other parameters are shown in Table 1.

Table 1. Flow rates of media and parameters of the process of NO oxidation by ozone in the flow reactor

\begin{tabular}{|l|c|c|}
\hline \multicolumn{1}{|c|}{ Parameter } & Unit & Value \\
\hline Volumetric flow rate of the carrier gas (air) & $\mathrm{m}^{3} / \mathrm{h}$ & 20 \\
\hline $\begin{array}{l}\text { Volumetric inflow rate of gas }\left(\mathrm{N}_{2}+2.5 \%_{\mathrm{vol}} \text {. of NO) from the }\right. \\
\text { cylinder }(2)\end{array}$ & $\mathrm{dm}^{3} / \mathrm{h}$ & $80 \div 90$ \\
\hline Reynolds number, $R e=u \cdot D / v$ & - & 8000 \\
\hline Initial concentration of NO & $\mathrm{pmm}$ & 100 \\
\hline Volumetric flow rate of oxygen through the ozonizer & $\mathrm{dm}^{3} / \mathrm{h}$ & 150 \\
\hline $\begin{array}{l}\text { Volumetric inflow rate of oxygen }+ \text { ozone into the oxidizing } \\
\text { reactor }(12)\end{array}$ & $\mathrm{dm}^{3} / \mathrm{h}$ & 135 \\
\hline Mole fraction of ozone in oxygen & $\mathrm{g} / \mathrm{m}^{3}$ & $10 \div 20$ \\
\hline Molar ratio, & $(\mathrm{mol} / \mathrm{s}) /(\mathrm{mol} / \mathrm{s})$ & $0.75 \div 1.50$ \\
\hline Temperature of the ozone destructor & ${ }^{\circ} \mathrm{C}$ & 175 \\
\hline Electric power of the ozone generator & $\mathrm{W}$ & $50 \div 120$ \\
\hline
\end{tabular}

The effectiveness of NO oxidation hereinafter called oxidation ratio, $O R$, was introduced applying the formula:

$$
O R=\left(1-\frac{\left[N O_{\text {out }}\right]}{\left[N O_{\text {ref }}\right]}\right) \cdot 100 \%
$$

where $\mathrm{NO}_{\text {ref }}$ denotes the initial mole fraction of NO.

\section{RESULTS AND DISCUSSION}

\subsection{The influence of the residence time on the effectiveness of $\mathrm{NO}$ oxidation by ozone}

The total rate of a chemical reaction in a chemical reactor depends on chemical kinetics represented by the characteristic reaction time and the mixing time of reactants (Frank-Kameneckij, 1987). This part of the studies was devoted to the explanation which of these factors is predominant for the effectiveness of NO oxidation by ozone $(O R)$.

This experiment was conducted using the laboratory apparatus described in the previous publication (Jakubiak and Kordylewski, 2010). Two air-like streams containing NO and ozone collided at the right angle in the glass reactor and rapidly mixed and then were flowing down the long tubular reactor. The time of residence $\tau_{\text {res }}$ after mixing varied from 0.2 to $4.2 \mathrm{~s}$ by adding next segments of a pipe before the gas analyzer. The results of the measurements of the oxidation ratio $O R$ depending on $\tau_{\text {res }}$ was shown in Fig. 4. 


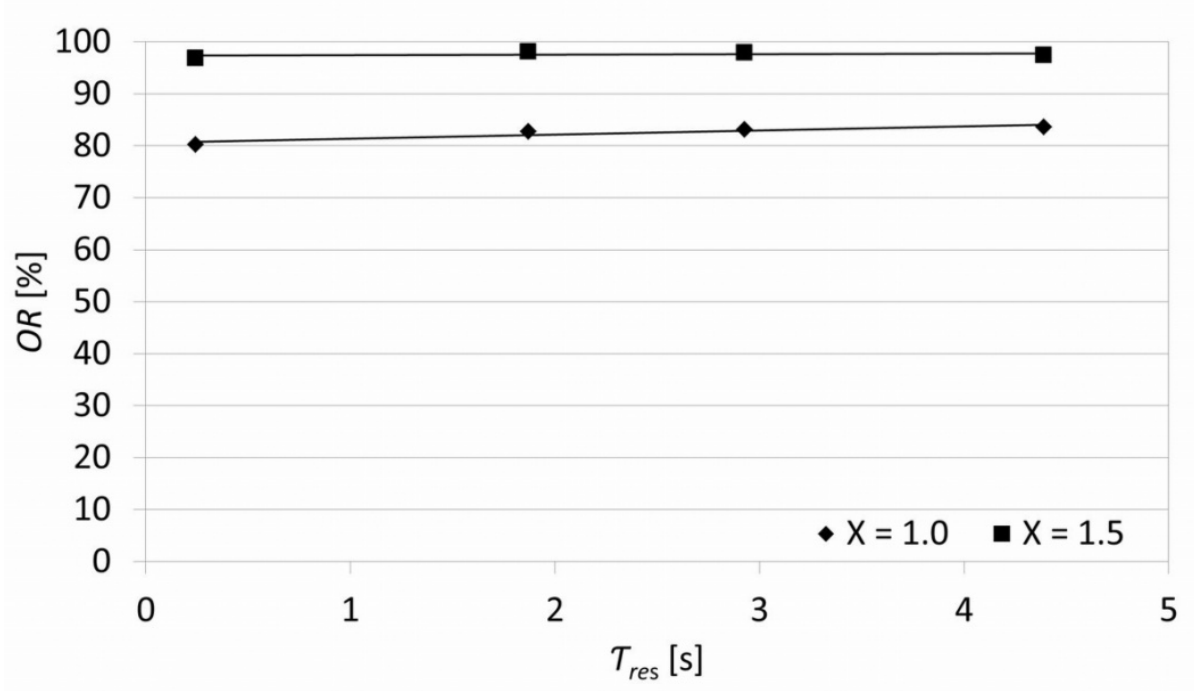

Fig. 4. Influence of the residence time $\tau_{\text {res }}$ on the oxidation ratio $O R$

Fig. 4 shows that the influence of the residence time $\tau_{\text {res }}=0.2 \div 4.2 \mathrm{~s}$ on the oxidation ratio $O R$ was very weak (for $X=1.0$ ) or none (for $X=1.5$ ). This result confirmed that the chemical reaction (1) is fast and that the total rate of $\mathrm{NO}$ oxidation by ozone could be diminished by mixing imperfection.

\subsection{The influence of the flow pattern on the effectiveness of $\mathrm{NO}$ oxidation by ozone}

The profiles of mole fractions of $\mathrm{NO}$ and $\mathrm{NO}_{2}$ in the carrier gas were measured at the 12 measurement sites in the axis of the flow reactor (12), starting from $0.1 \mathrm{~m}$ after the ozone injection site, and next after every $0.1 \mathrm{~m}$, up to $1.2 \mathrm{~m}$ (Fig. 2).

\subsubsection{Axial profiles of mole fractions of $\mathrm{NO}$ and $\mathrm{NO}_{2}$}

An example of variation of mole fractions of $\mathrm{NO}, \mathrm{NO}_{2}$ and $\mathrm{NO}_{\mathrm{x}}$ measured in the axis of the flow reactor for co-current ozone injection from a single nozzle and for the molar ratio $X=1.0$ is shown in Fig. 5.

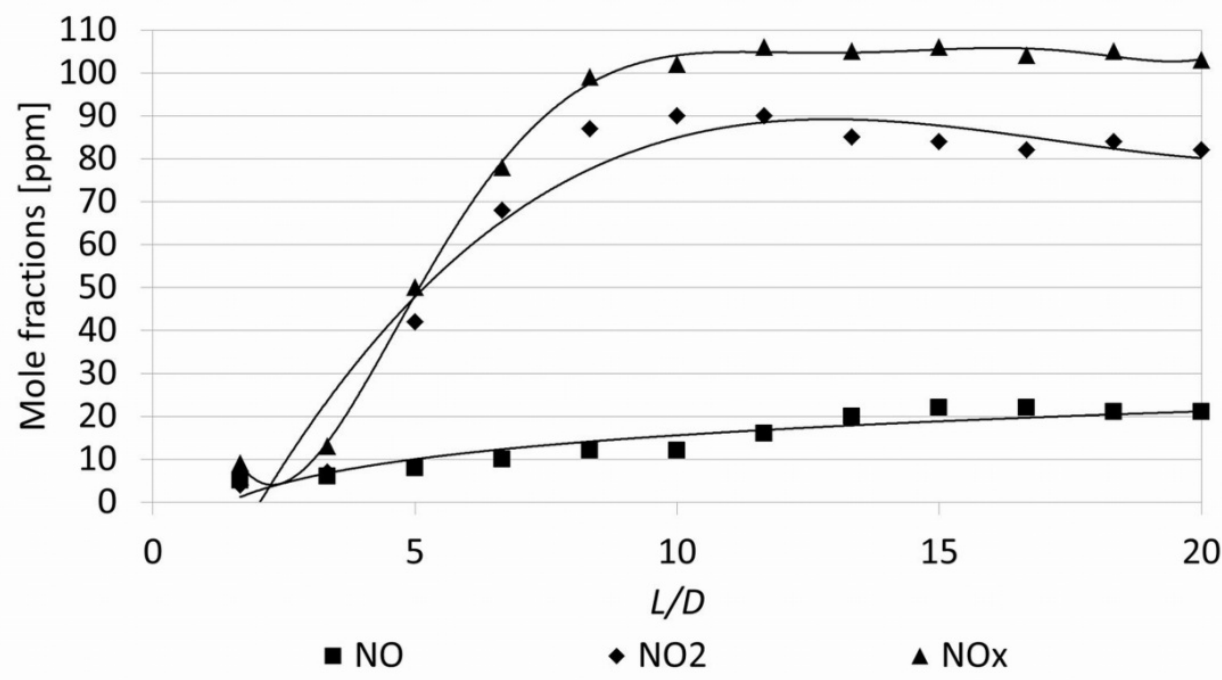

Fig. 5. Axial profiles of mole fractions of $\mathrm{NO}, \mathrm{NO}_{2}$ and $\mathrm{NO}_{\mathrm{x}}$ for $n=1$ and $X=1.0$ (co-current injection) 
Due to the ozone injection from a single nozzle on the axis of the reactor the mole fractions of NO and $\mathrm{NO}_{2}$ measured directly after the nozzle outlet were very low, which was the result of high mole fraction of $\mathrm{O}_{2}+\mathrm{O}_{3}$ just after the nozzle. With an increase of a distance from the injection site the mole fractions of $\mathrm{NO}_{2}$ and $\mathrm{NO}_{\mathrm{x}}$ quickly increased as a result of $\mathrm{NO}$ diffusion from the carrier gas and its oxidation by ozone according to the chemical reaction (1). The final composition state was achieved approximately after 10 diameters $D$ from the injecting nozzle, although the oxidation of NO was not complete, perhaps because of imperfect mixing.

The axial profiles of the fractions of $\mathrm{NO}$ and $\mathrm{NO}_{2}$ measured for counter-current injection of ozone (Fig. 6) were very different from these in Fig. 5. In this case mixing of ozone with the carrier gas was much faster, because the mole fractions of $\mathrm{NO}$ and $\mathrm{NO}_{2}$ were smooth almost immediately after the injection site.

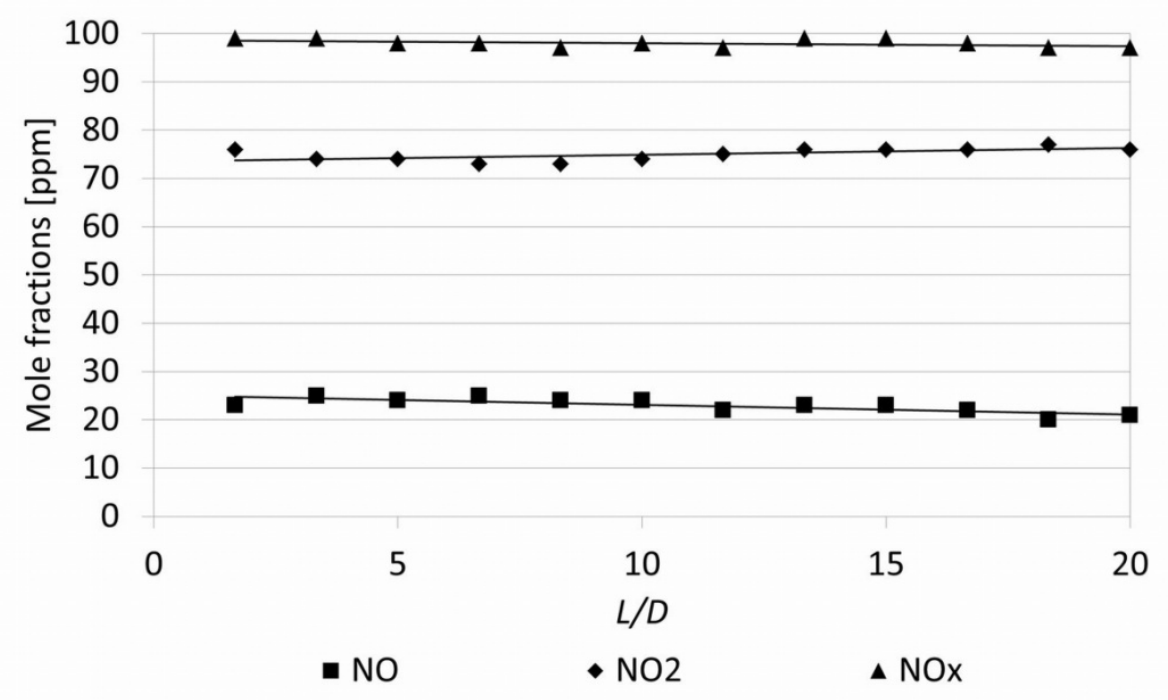

Fig. 6. Axial profiles of mole fractions of $\mathrm{NO}, \mathrm{NO}_{2}$ and $\mathrm{NO}_{\mathrm{x}}$ for $n=1$ and $X=1.0$ (counter-current injection)

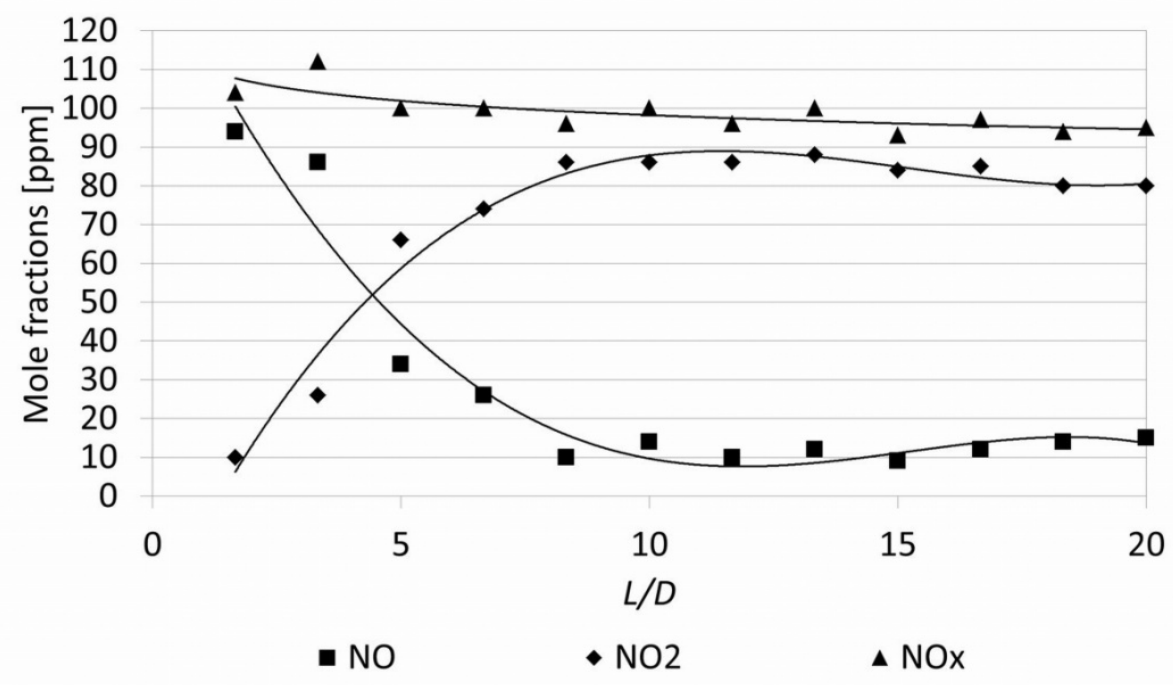

Fig. 7. Axial profiles of mole fractions of $\mathrm{NO}, \mathrm{NO}_{2}$ and $\mathrm{NO}_{\mathrm{x}}$ along the axis of the flow reactor for $n=2$ and $X=1.0$ (co-current injection)

A comparison of co- and counter-current dispersion rates in the flowing carrier gas when ozone was injected through two nozzles is shown in Figs. 7 and 8 for the molar ratio $X=1.0$. In contrast to the 
injection of ozone by a single nozzle (Fig. 5), the summary mole fraction $\mathrm{NO}_{\mathrm{x}}=\mathrm{NO}+\mathrm{NO}_{2}$ was approximately equal to the reference value $\left[N O_{x}\right]=100 \mathrm{ppm}$ for the co-current ozone injection (Fig. 7). The mole fraction of $\mathrm{NO}$ was declining gradually from the initial $[N O]=100 \mathrm{ppm}$ up to approximately $[N O]=10 \mathrm{ppm}$ after the distance $L / D=10$ from the injection site.

For counter-current ozone injection by the two nozzles the axial profiles of the mole fractions of NO, $\mathrm{NO}_{2}$ and $\mathrm{NO}_{\mathrm{x}}$ (Fig. 8) were similar to these in Fig. 6, for counter-current injection from the single nozzle. Some delay in smoothness of the profiles resulted from ozone diffusion into the axis of the reactor from where the gas samples were collected.

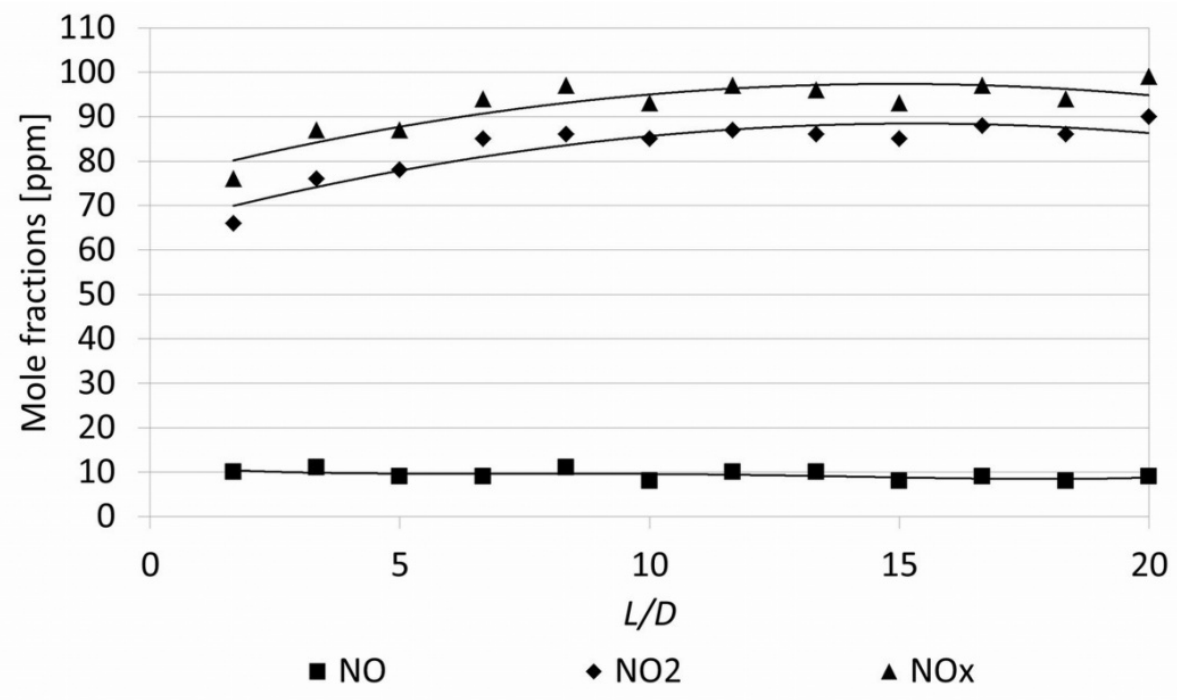

Fig. 8. Axial profiles of mole fractions of $\mathrm{NO}, \mathrm{NO}_{2}$ and $\mathrm{NO}_{\mathrm{x}}$ for $n=2$ and $X=1.0$ (counter-current injection)

\subsubsection{Influence of the number of nozzles on the effectiveness of $N O$ oxidation by ozone}

The influence of the number of ozone injecting nozzles on the effectiveness of NO oxidation was examined by the determination of the oxidation ratio $\mathrm{OR}$. The measurements of $[\mathrm{NO}]$ and $\left[\mathrm{NO}_{2}\right]$ were made at the end of the flow reactor $(L / D=20)$ for the molar ratio $X=0.75,1.0$ and 1.5. The results are shown in Figs. 9 and 10.

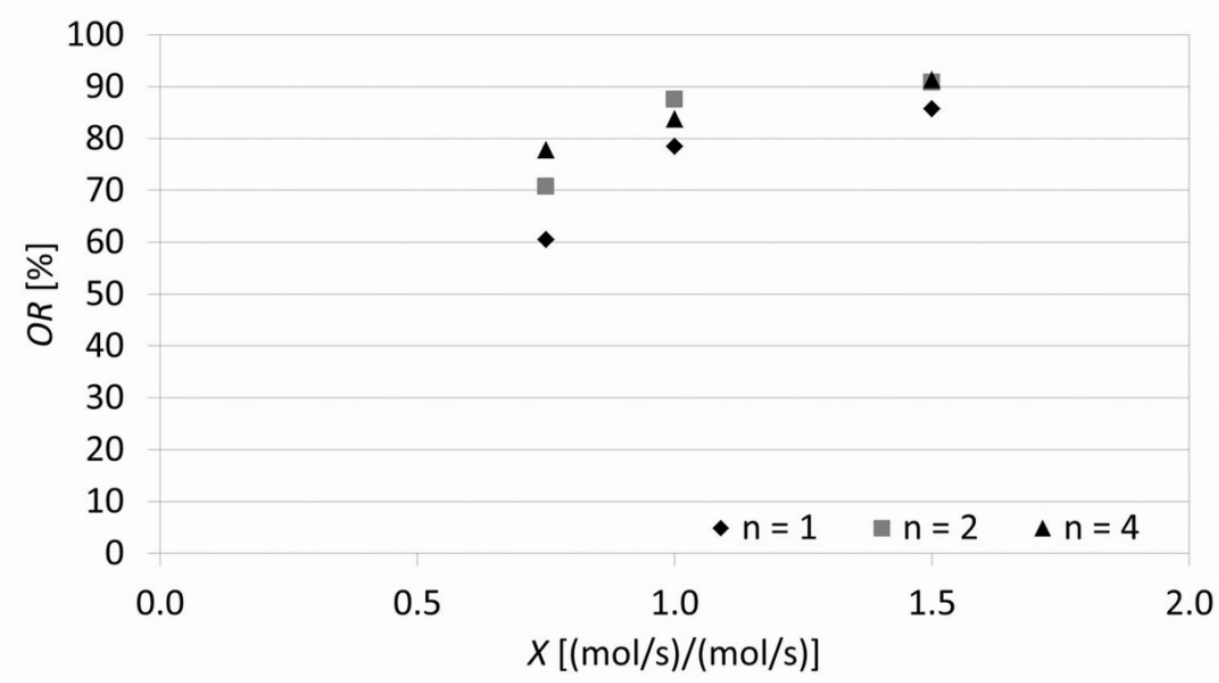

Fig. 9. Effect of the number of ozone injecting nozzles on the oxidation ratio $O R$ for co-current injection 


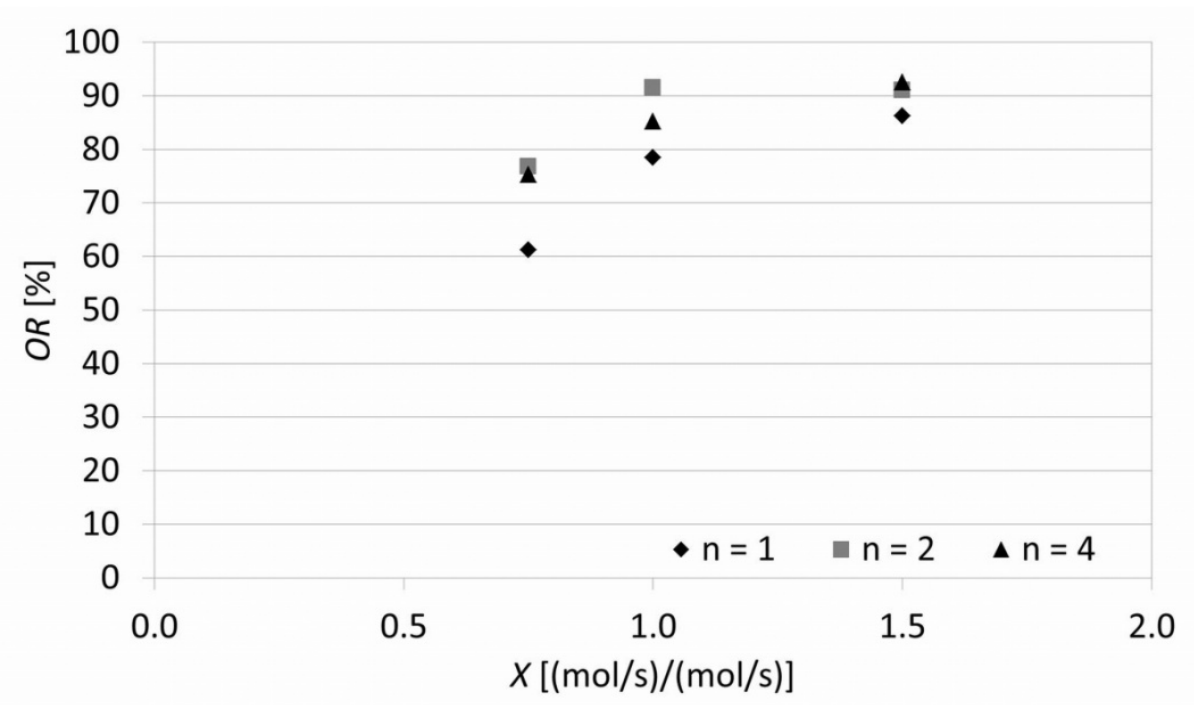

Fig. 10. Effect of the number of ozone injecting nozzles on the oxidation ratio $O R$ for counter-current injection

For both systems of ozone injection (co- and counter-current) the effectiveness of NO oxidation $O R$ improved with the increase of the number of nozzles. However, the observed effect appeared to be most apparent for the smallest molar ratio $(X=0.75)$ and least important for the overstoichiometric molar ratio $(X=1.5)$.

\subsubsection{Influence of the injection pattern on the effectiveness of $N O$ oxidation}

The effect of co- and counter-current injection of ozone on the effectiveness of NO oxidation is presented in Fig. 11 for four nozzles of the injecting system. The $\mathrm{NO}$ and $\mathrm{NO}_{2}$ mole fractions were measured at the end of the flow reactor $(L / D=20)$ depending on the molar ratio $X=0.75 \div 1.50$.

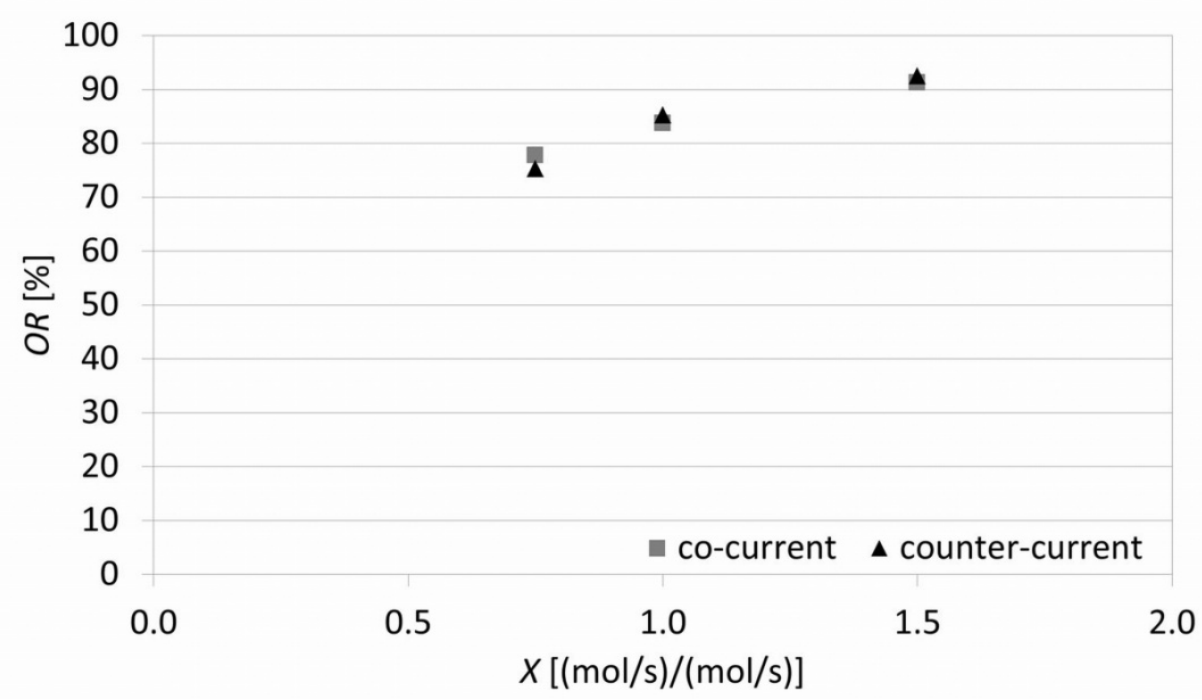

Fig. 11. The effect of the injection pattern $(n=4)$ on the oxidation ratio $O R$ vs. the molar ratio $X$

It turns out that after such a long distance from the ozone injection site $(L / D=20)$ there is no distinct difference between the effectiveness of NO oxidation by ozone for the co- and counter-current injection pattern. Similar results were obtained for ozone injection by one and two nozzles. 


\section{CONCLUSIONS}

The analysis of the obtained results from the conducted studies leads to the following conclusions:

- The chemical reaction (1) of $\mathrm{NO}+\mathrm{O}_{3}$ is fast, hence the effectiveness of nitrogen monoxide oxidation by ozone injected into a flow reactor could be influenced by the process of mixing.

- The maximum effectiveness of NO oxidation by ozone $\mathrm{OR} \approx 90 \%$ was achieved at the end of the tubular flow reactor for the molar ratio $\mathrm{X}=1.5$.

- The counter-current injection appeared to be superior to co-current injection for NO oxidation conducted a short distance $(\mathrm{L} / \mathrm{D}<10)$ from the ozone injection site.

- In areas located further from the ozone injection site $(\mathrm{L} / \mathrm{D}=20)$ both injection systems were practically equally effective.

- At the end of the reactor the effectiveness of NO oxidation improved with the number of ozone nozzles for $\mathrm{X} \leq 1$, but it appeared to be meaningless at overstoichiometric conditions $(X>1)$.

- In practice the counter-current injection mode has an advantage over the co-current mode because it helps to save space necessary for NO oxidation reactor which is located before the absorption vessel.

The results presented in this paper were obtained from research work co-financed by the National Centre of Research and Development in the framework of Contract SP/E/1/67484/10 - Strategic Research Programme - Advanced technologies for obtaining energy: Development of a technology for highly efficient zero-emission coal-fired power units integrated with $\mathrm{CO}_{2}$ capture.

\section{SYMBOLS}

d inner diameter of the nozzle, $\mathrm{m}$

D inner diameter of the reactor, $\mathrm{m}$

$L \quad$ length of the reactor, $m$

$n$ number of nozzles,

[NO] mole fraction of $\mathrm{NO}$, ppm

$\left[\mathrm{NO}_{2}\right] \quad$ mole fraction of $\mathrm{NO}_{2}, \mathrm{ppm}$

$\left[\mathrm{NO}_{x}\right] \quad$ sum of the $[\mathrm{NO}]$ and $\left[\mathrm{NO}_{2}\right]$, ppm

$\left[N O_{\text {out }}\right]$ output NO mole fraction, ppm

$\left[N O_{r e f}\right] \quad$ reference NO mole fraction, ppm

OR oxidation ratio of $\mathrm{NO}, \%$

Re forward Reynolds number,

$u$ mean flow velocity in the reactor, $\mathrm{m} / \mathrm{s}$

$X \quad$ molar ratio, $(\mathrm{mol} / \mathrm{s}) /(\mathrm{mol} / \mathrm{s})$

Greek symbols

$\tau_{\text {res }} \quad$ residence time, $\mathrm{s}$

$v \quad$ kinematics viscosity, $\mathrm{m}^{2} / \mathrm{s}$

$\gamma \quad$ flux of moles, $\mathrm{mol} / \mathrm{s}$

\section{Superscripts}

out output

ref reference

res residence 


\section{REFERENCES}

Carlin N.T., Annamalai K., Harman W.L., Sweeten J.M., 2009. The economics of reburning with cattle manurebased biomass in existing coal-fired power plants for $\mathrm{NO}_{\mathrm{x}}$ and $\mathrm{CO}_{2}$ emissions control, Biomass Bioenergy. 33 , 1139-1157. DOI: 10.1016/j.biombioe.2009.04.007.

Directive2010/75/EU of the European Parliament and of the Council, 2010.

Directive2001/80/EC of the European Parliament and of the Council, 2001.

Błasiak W., 2008.Fuel switch from fossil to $100 \%$ biomass on tangential fired PC boiler. POWER-GEN Europe. Milan, Italy,3-5 June2008.

Ellison W., 2003. Chemical process design alternatives to gain simultaneous $\mathrm{NO}_{\mathrm{x}}$ removal in scrubbers, POWERGEN International. Las Vegas, USA, 9-11December 2003.

Frank-Kameneckij D.A., 1987. Diffusion and heat transfer in chemical kinetics (in Russian), Nauka, Moskva.

Jakubiak M., Kordylewski W., 2010. Effectiveness of $\mathrm{NO}_{\mathrm{x}}$ removal from gas via peroxidation of NO with ozone and absorption in alkaline solutions. Chem. Process Eng., 31, 699-709.

Kordylewski W., Zacharczuk W., Hardy T., Kaczmarczyk J., 2005. The effect of the calcium in lignite on its effectiveness as a return fuel. Fuel, 84, 1110-1115. DOI: 10.1016/j.fuel.2004.10.014.

Maly P. M., Zamansky V. M., Ho L., Payne R., 1999. Alternative fuel reburning. Fuel, 78, 327-334. DOI: 10.1016/S0016-2361(98)00161-6.

Nelo S.K., Leskela K.M., Sohlo J.J.K., 1997. Simultaneous oxidation of nitrogen oxides and sulfur dioxide with ozone and hydrogen peroxide. Chem. Eng. Technol., 20, 40-42. DOI: 10.1002/ceat.270200108.

NIST, 2010. Chemical Kinetics Database, User's Guide (Internet).

Ozonek J., 2003. Analysis of ozone production processes for environmental protection (in Polish), PAN, Lublin.

Prather M.J., Logan J.A., 1994.Combustion's impact on the global atmosphere. 25th Symposium. (International) on Combustion. Pittsburgh, USA,31 July - 5 August 1994, 1513-1527.

Puri I. K., 1995. Removal of NO by Low-Temperature $\mathrm{O}_{3}$ Oxidation. Combust. Flame, 102, 512-518. DOI: 10.1016/0010-2180(95)00042-5.

Schimmoller B. K., 2003. Lack of environmental certainty renews emphasis on low-cost emissions control. Power Eng., Sept. 1, 32-38.

Van der Kooij J. et al., 1997. Selective catalytic reduction (SCR), long-term experience and test procedures. Thermal Generation Study Committee, 20.03 THERNOX, Paris, UNIPEDE, 1997.

Vosteen B. W., Kanefke R., Köser H., 2006. Bromine-enhanced Mercury Abatement from Combustion Flue Gases - Recent Industrial Applications and Laboratory Research. VGB Power Tech, 3, 70-75.

Wang Z., Zhou J., Fan J., Cen K., 2006. Direct numerical simulation of ozone injection technology for $\mathrm{NO}_{\mathrm{x}}$ control in flue gas. Energy Fuels, 20, 2432-2438. DOI: 10.1021/ef0603176.

Wang Z., Zhou J., Zhu Y., Wen Z., Liu J., Cen K., 2007. Simultaneous removal of $\mathrm{NO}_{\mathrm{x}}, \mathrm{SO}_{2}$ and $\mathrm{Hg}$ in nitrogen flow in a narrow reactor by ozone injection: Experimental results. Fuel Process. Technol., 88, 817-823. DOI: 10.1016/j.fuproc.2007.04.001.

Werle S., Wilk R.K., 2011. Reburning potential of gas from the sewage sludge gasification process. Arch. Combust., 31, 55-62. 